Jurnal IImiah: Biologi Eksperimen dan Keanekaragaman Hayati

Vol. 1 No. 2 Juli 2013: hal. 96 - 102

ISSN: 2338-4344

\title{
INVENTARISASI JENIS - JENIS JAMUR PADA TANAMAN KAKAO (Theobroma cacao L.) DI KABUPATEN PESAWARAN
}

\author{
Muhamad Irham Arfani ${ }^{1}$, Yulianty ${ }^{1}$, Martha Lulus Lande ${ }^{1}$ \\ ${ }^{1}$ Jurusan Biologi FMIPA Universitas Lampung \\ e-mail :Irham_arfani@yahoo.com \\ Jurusan Biologi FMIPA Universitas Lampung \\ JI. Soemantri Brojonegoro No.1, Bandar Lampung, Lampung, Indonesia, 35145
}

\begin{abstract}
Abstrak
Kakao merupakan komoditas unggulan yang tersebar hampir di seluruh Kabupaten di Lampung termasuk Kabupaten Pesawaran. Budidaya kakao di Pesawaran masih bersifat tradisional sehingga menyebabkan tanaman kakao rentan terserang penyakit seperti jamur dan akhirnya menurunkan mutu dan jumlah hasil panen. Penelitian ini bertujuan untuk mengidentifikasi jenis-jenis jamur patogen dan saprofit pada tanaman kakao (Theobroma cacao L.). Penelitian ini dilaksanakan di Kabupaten Pesawaran dan Laboratorium Botani FMIPA Universitas Lampung, dari bulan Juli sampai Desember 2012. Pengambilan spesimen dilakukan secara eksploratif di lima Kecamatan di Pesawaran yaitu Punduh Pidada, Gedong Tataan, Tegineneng, Padang Cermin, dan Kedondong. Pengamatan gejala serangan berupa munculnya miselium dan bercak pada organ tanaman kakao dilakukan secara makroskopis dan pengamatan secara mikroskopis dilakukan untuk mengamati bentuk, warna, dan ukuran spora. Dari hasil penelitian ditemukan 16 jenis jamur yang tergolong dalam 4 kelas. Satu jenis termasuk kelas Oomycetes, Satu jenis termasuk kelas Zygomycetes, 13 jenis jenis termasuk kelas Deuteromycetes dan satu jenis termasuk kelas Basidiomycetes.
\end{abstract}

Kata kunci : inventarisasi, jamur, dan tanaman kakao (Theobroma cacao L.)

\begin{abstract}
Cocoa Plantations are spread almost all over districts in Lampung Province including Pesawaran. In the Pesawaran cocoa is cultivated conventionally and it may cause the cocoa susceptible to diseases such as fungi, as a result reduces the quality and quantity of yield. To identify the type of pathogen and saprophyte fungi in cocoa (Theobroma cacao L.), the study was conducted in the Laboratory of Botany Lampung University, from July to December 2012. Specimens were collected by exploratory study in 5 subdistricts of Pesawaran namely Punduh Pidada, Gedong Tataan, Tegineneng, Padang Cermin, and Kedondong. Identification of samples were done macroscopically and microscopically. Observations of symptoms of mycelium or patches contained in the cocoa plant organs were done directly while the fungi shape, color, and size of the spores were identified under microsscope. There were 16 species of fungi found. One species belong to the class Oomycetes, one species belongs to the class Zygomycetes, 13 species belong to the class Deuteromycetes and 1 species belong to the class Basidiomycetes
\end{abstract}

Key word: inventory, fungi and plants cocoa (Theobroma cacao L.)

\section{PENDAHULUAN}

Kakao merupakan salah satu komoditas perkebunan unggulan Provinsi Lampung yang tersebar hampir diseluruh Kabupaten di Provinsi Lampung. Luas areal tanaman kakao yang dikelola oleh rakyat di Provinsi Lampung pada tahun 2009 mencapai 39.576 Ha dengan produksi 27.429 ton, sedangkan milik swasta luas areal kakao mencapai $3.198 \mathrm{Ha}$ dengan produksi 4.037 ton. (Dinas Perkebunan Lampung, 2013).

Keberhasilan perluasan areal tersebut telah memberikan hasil nyata bagi peningkatan pasar kakao di dunia. Indonesia berhasil menempatkan diri sebagai produsen kakao terbesar kedua setelah Pantai Gading pada tahun 2002. Walaupun kembali tergeser ke posisi ketiga oleh Ghana pada tahun 2003 dan pada akhir tahun 2011 ini, Indonesia kembali menempati posisi kedua menggeser Ghana dengan peningkatan produksi menjadi 850 ribu ton (Direktorat Jenderal Perkebunan, 2012).

Produksi kakao di Indonesia cukup tinggi namun mutunya kurang baik. Penanganan tanaman yang masih tradisional diduga sebagai penyebab utamanya, sehingga berat dan bentuk biji relatif kecil. Selain itu kurangnya penge- 
tahuan dan informasi bagi petani kakao tentang jenis hama dan penyakit kakao, terutama penyakit yang disebabkan oleh jamur yang menyebabkan mutu dan produksi kakao menjadi rendah (Sulistiowati dkk., 2003).

Menurut Semangun (2003), terdapat jenis jamur patogen pada tanaman kakao, dan penyakit yang sering ditemukan seperti Vascular streak dieback (VSD) yang disebabkan oleh Oncobasidium theobromae, busuk buah disebabkan oleh Phytophthora palmivora, Rhizopus stolonifer dan Botrytis cinerea, kanker batang disebabkan oleh Phytophthora palmivora, dan antraknosa disebabkan oleh Colletotrichum gloeosporioides (Junianto, 1993)

Inventarisasi jenis-jenis jamur yang terdapat pada tanaman kakao di Pesawaran belum banyak dilakukan padahal informasi tentang hal ini sangat dibutuhkan untuk meningkatan mutu dan produksi kakao.

\section{BAHAN dan METODE}

Penelitian ini telah dilakukan di lima Kecamatan di Kabupaten Pesawaran dan Laboratorium Botani Jurusan Biologi FMIPA Universitas Lampung dari bulan Juli sampai Desember 2012.

Sampel tanaman kakao (Theobroma cacao L.) yang terinfeksi jamur dikumpulkan dari 5 Kecamatan di Pesawaran antara lain Padang Cermin, Punduh Pidada, Tegineneng, Gedong Tataan, dan Kedondong.

Metode pengambilan sampel yaitu dengan metode eksploratif. Bagian-bagian tanaman kakao yang menunjukkan gejala serangan jamur dikumpulkan dan dimasukkan ke dalam koran yang telah dibentuk amplop, kemudian diberi label, nomor koleksi, lokasi, nama kolektor. Pengamatan dilakukan dengan 2 cara yaitu pengamatan secara makroskopis dan pengamatan secara mikroskopis.

Pengamatan makroskopis dilakukan dengan cara mengamati langsung gejala penyebab penyakit yang tampak pada bagian daun, buah, batang maupun akar. Pengamatan secara mikroskopis dilakukan setelah ditemukannya penyakit pada bagian batang, daun, buah tanaman yang terserang jamur.

Pengamatan dilakukan di bawah mikroskop dimulai dari perbesaran 10x kemudian dilanjutkan dengan pembesaran 100x. Minyak imersi diperlukan untuk mempertajam tampilan di mikroskop (Hawksworth, 1974). Identifikasi dilakukan dengan menggunakan buku identifikasi dari Barnett and Hunter (1988), Booth (1971), Chupp (1953), Ellis (1971), Ellis (1976), Hanlin (1989) dan Sutton (1980).

\section{HASIL dan PEMBAHASAN}

Dari penelitian ini telah ditemukan enam belas jenis jamur yang termasuk dalam empat kelas. Satu jenis termasuk ke dalam kelas Oomycetes, satu jenis termasuk ke dalam kelas Zygomycetes, 13 jenis termasuk ke dalam kelas Deuteromycetes dan satu jenis termasuk ke dalam kelas Basidiomycetes. Jenis-jenis jamur tersebut dapat dilihat pada Tabel 1.

Daerah perkebunan coklat di Pesawaran yang paling banyak mengalami kerusakan akibat serangan jamur adalah Kecamatan Padang Cermin, diduga karena letak perkebunan kakao yang berada dikawasan pegunungan dan sistem pertanian yang masih bersifat tradisional. Berdasarkan data Kabupaten Pesawaran (2010), daerah Padang Cermin memiliki ketinggian 1.604 mdpl, temperatur udara berkisar 26 ${ }^{\circ} \mathrm{C}$ sampai dengan $29{ }^{\circ} \mathrm{C}$ dan memiliki curah hujan per tahun berkisar $2.264 \mathrm{~mm}$ sampai dengan $2.868 \mathrm{~mm}$.

Bagian tanaman kakao yang paling banyak diserang jamur adalah buah dan daun. Bagian buah dan daun mudah terserang jamur, karena dinding penyusun daun dan buah tersusun dari selulosa dan hampir semua fungi mempunyai enzim selulase yang mampu mendegradasi selulosa (Serf and Macnab, 1986). Bagian tanaman yang jarang diserang jamur adalah bagian batang, karena pada bagian batang terdapat kandungan lignin yang membuat jamur lebih sulit melakukan penetrasi dibandingkan dengan daun dan buah (Hammel,1997). Jamur dari kelas Basidiomycetes memiliki kemampuan untuk mendegradasi senyawa lignin (Mendonca et al., 2008)

Jenis jamur yang paling banyak ditemukan pada tanaman kakao berasal dari kelas Deuteromycetes yaitu 13 jenis jamur. Jamur kelas Deuteromycetes memiliki sistem reproduksi secara vegetatif atau aseksual. Sistem reproduksi secara aseksual lebih cepat perkembangan dan penyebarannya daripada sistem reproduksi secara seksual, karena untuk terjadinya sistem reproduksi secara seksual dibutuhkan sepasang gamet yang kompatibel (John and Keith, 1996). 
Tabel 1. Jenis-jenis jamur pada tanaman kakao di Pesawaran

\begin{tabular}{|c|c|c|c|c|}
\hline No. & Kelas & Jenis & $\begin{array}{l}\text { Bagian yang } \\
\text { Diserang }\end{array}$ & Daerah Sebaran \\
\hline 1 & Oomycetes & Phytophthora palmivora (Butl.) Butl. & Buah & Padang Cermin \\
\hline 2 & Zygomycetes & Botrytis cinerea Pers. Ex Pers. & Buah & Tegineneng, Padang Cermin \\
\hline \multirow[t]{12}{*}{3} & \multirow[t]{12}{*}{ Deuteromycetes } & Botryodiplodia theobromae Sacc. & Buah, Daun & $\begin{array}{l}\text { Padang Cermin, Gedong Tataan, } \\
\text { Tegineneng, Kedondong, Punduh } \\
\text { Pidada }\end{array}$ \\
\hline & & Cercospora sp. Fresenius & Buah & Padang Cermin \\
\hline & & Cladosporium tenuissimum Cooke & Buah & Padang Cermin \\
\hline & & Colletotrichum capsici Corda & Buah & Padang Cermin \\
\hline & & Diplodina sp. Westend. & Buah, Daun & Padang Cermin, Kedondong \\
\hline & & Drechslera teresSacc. & Daun & Padang Cermin \\
\hline & & Fusarium acuminatum Ellis \& Everhart & Buah & Padang Cermin, Kedondong \\
\hline & & Fusarium solani var. coeruleum (Sacc) & Buah & Padang Cermin, Punduh Pidada \\
\hline & & Fusarium decemcellulare Brick. & Buah & Padang Cermin \\
\hline & & Hendersonia sp. Sacc. & Buah & Padang Cermin \\
\hline & & Hysteropycnis sp. Zogg. & Buah & Padang Cermin \\
\hline & & Periconia sp. Tode ex Fries & Daun & Tegineneng \\
\hline 4 & Basidiomycetes & $\begin{array}{l}\text { Ganoderma pseudoferreum (Wakef) Ov. } \\
\text { Et Stein }\end{array}$ & Batang & Padang Cermin \\
\hline
\end{tabular}

Botryodiplodia theobromae, Fusarium decemcellulare dan Phytophthora palmivora adalah jenis jamur yang spesifik inang pada tanaman kakao, karena jamur-jamur ini pernah ditemukan menyerang tanaman kakao dan menyebabkan kerugian yang berbeda-beda di tiap daerah. Berdasarkan Buku Indeks Tanaman Inang, telah ditemukan 42 jenis jamur pada tanaman kakao di Indonesia dan diantaranya adalah Botryodiplodia theobromae, Fusarium decemcellulare dan Phytophthora palmivora (Semangun, 2000).

Fusarium decemcellulare ditemukan pada bagian buah kakao di Kecamatan Padang Cermin. Brunt dan Wharton (1962) melaporkan bahwa Fusarium decemcellulare adalah penyebab chusion empedu atau titik hijau empedu pada bagian daun tanaman kakao.

Botryodiplodia theobromae ditemukan pada bagian daun dan buah. Penyakit busuk buah ini menyebar merata di seluruh Kecamatan di Kabupaten Pesawaran. Karena temperatur ratarata perkebunan kakao berkisar antara 18,8$30,4 \stackrel{\circ}{\circ} \mathrm{C}$, dengan kelembapan antara $90-95 \%$. $\mathrm{Hal}$ ini sesuai dengan pernyataan Cooke et al. (2004), bahwa penyakit busuk Botryodiplodia akan cepat berkembang pada suhu antara 29$30^{\circ} \mathrm{C}$, dengan kelembapan antara $92-96 \%$.

Dari kelas Oomycetes ditemukan satu jenis, yaitu Phytophthora palmivora. Berdasarkan penelitian-penelitian yang dilakukan di Indonesia, jenis jamur ini banyak menyerang buah kakao (Zaenudin, 2010; Junianto, 1993). Phytophthora palmivora dikenal sebagai penyebab utama busuk buah pada tanaman kakao (Hislop, 1964). Hislop (1964) mengatakan, jamur Phytophthora palmivora membutuhkan air untuk melakukan proses perkecambahan sporanya.

Dari Kelas Zygomycetes ditemukan satu jenis, yaitu Botrytis cinerea. Menurut Junianto (1993), jenis jamur ini banyak menyerang buah kakao mulia atau kultivar criollo di Kaliwining Jawa Timur. Menurut Samosir (2007), jamur ini sangat cepat menyebar ke buah yang ada di dekatnya.

Dari Kelas Basidiomycetes ditemukan satu jenis, yaitu Ganoderma pseudoferreum. Ganoderma pseudoferreum terdapat pada bagian batang tanaman kakao. Menurut Zaenudin (2010), jenis jamur ini banyak menyerang tanaman kakao di Indonesia. Subowo (2009), menyatakan bahwa marga Ganoderma memiliki enzim ligninase yang mampu mendegradasi lignin pada bagian batang tanaman.

\section{Periconia sp. Tode ex Fries}

Koloni berbentuk seperti kapas, atau tidak beraturan. Konidia elips, hialin, permukaan bergerigi, tidak bersekat dengan ukuran konidia berkisar antara 11-13 $\mu \mathrm{m}$. Banyak ditemukan pada bagian daun kakao. 


\section{Botryodiplodia theobromae Sacc.}

Konidia tak bersekat dan tipis ketika muda, kemudian membentuk satu sekat dan berwarna coklat gelap ketika dewasa. Sekat di tengah konidia berdinding tipis dan berwarna coklat gelap dengan lebar 3-4 $\mu \mathrm{m}$, panjang konidia 19-34 $\mu \mathrm{m}$ dan lebar konidia 11-16 $\mu \mathrm{m}$. Penyebarannya luas, ditemukan pada bagian buah dan daun kakao.

\section{Cladosporium tenuissimum Cooke}

Bentuk konidia bermacam-macam, berwarna coklat zaitun muda, permukaan lembut atau verruculose (bergerigi), dengan ukuran panjang konidia 3 - $20 \mu \mathrm{m}$ dan lebar 3 - $6 \mu \mathrm{m}$. Penyebarannya kosmopolit dan ditemukan pada bagian buah kakao.

\section{Botrytis cinerea Pers. Ex Pers.}

Warna koloni abu-abu dengan bagian ujung berwarna coklat, bagian permukaan koloni rata, bentuk tepi koloni bulat. Percabangan konidia berbentuk obovoid, berwarna coklat pucat, berdinding halus, panjang konidia 8-16 $\mu \mathrm{m}$ dan lebar konidia 6-9 $\mu \mathrm{m}$. Penyebarannya kosmopolitan, ditemukan pada bagian buah kakao.

\section{Phytophthora palmivora (Butl.) Butl.}

Warna koloni putih pada bagian permukaan, bagian dasar putih dengan pusat bintik-bintik hitam, permukaan koloni rata. Sporangiospora berbentuk bulat, bersel satu, berwarna cokelat keemasan, ukuran oospora 5-15 $\mu \mathrm{m}$. Penyebarannya luas, tipe habitatnya berair dan ditemukan pada bagian buah kakao.

\section{Drechslera teres Sacc.}

Konidia lurus. Jumlah pseudosepta berkisar 110. Konidia berukuran 4-200 $\mu \mathrm{m}$ dan ketebalan konidia 7-11 $\mu \mathrm{m}$. Sekat pada konidia tipis dan berwarna hitam, pada tiap sekat terdapat bulatan yang berwarna-warni, ditemukan pada bagian daun kakao.

\section{Cercospora sp. Fresenius}

Konidia hialin, lurus atau sedikit lurus, mempunyai banyak sekat, pada dasar konidia berbentuk truncate atau seperti kerucut yang dipotong ujungnya, ujung mengecil dan sedikit meruncing, panjang 25-125 $\mu \mathrm{m}$, dan lebar 3-5 $\mu \mathrm{m}$, ditemukan pada bagian buah kakao.

\section{Ganoderma pseudoferreum (Wakef) Ov. Et Stein}

Badan buah berbentuk setengah lingkaran, dengan ukuran jari-jari $9 \mathrm{~cm}$ dan memiliki ketebalan badan buah $3 \mathrm{~mm}$. Warna jamur kuning, ketika tua berwarna putih. Penyebaran kos- mopolitan dan ditemukan pada bagian batang kakao.

\section{Colletotrichum capsici Corda}

Konidia bersel 1, berbentuk bulan sabit, curved atau melengkung, dengan tepi lurus. Memiliki ukuran konidia 11-20 $\mu \mathrm{m}$ dan lebar 4-8 $\mu \mathrm{m}$, ditemukan pada bagian buah kakao.

\section{Diplodina sp. Westend.}

Konidia berwarna gelap, bersel 2, berbentuk bulat telur atau ovoid. Panjang konidia 11-30 $\mu \mathrm{m}$ dan lebar 7-15 $\mu \mathrm{m}$. Penyebarannya kosmopolit dan ditemukan pada bagian buah dan daun kakao.

\section{Hysteropycnis sp. Zogg}

Konidia bersel dua, di setiap bagian sel berbentuk segitiga, sekat tebal berwarna kuning, ukuran sekat 3-8 $\mu \mathrm{m}$. Memiliki ukuran konidia 15-30 $\mu \mathrm{m}$ dan ketebalan konidia 6-15 $\mu \mathrm{m}$, ditemukan pada bagian buah kakao.

\section{Hendersonia sp. Sacc.}

Konida berwarna gelap, beberapa sel memanjang, bersekat-sekat. Setiap sekat berbentuk bulat. Panjang konidia berukuran 12-40 $\mu \mathrm{m}$. Penyebarannya luas, ditemukan pada bagian buah kakao.

\section{Alternaria raphani Groves \& Skolko}

Konidia soliter, membentuk rantai pendek, lurus atau membengkok, oblacavate atau mengecil ke arah dasar, permukaan konidia halus, konidia umumnya dalam rantai kedua dan ketiga lurus atau sedikit melengkung, sedangkan pada rantai ketujuh berbentuk melintang. Konidia berukuran 50-130 $\mu \mathrm{m}$, dan ketebalan konidia 14-30 $\mu \mathrm{m}$, ditemukan pada bagian daun kakao.

\section{Fusarium acuminatum Ellis \& Everhart}

Konidia berbentuk bulan sabit, dengan bagian ujung berbentuk runcing seperti kail pancing, jumlah sekat 3-7. Ukuran konidia 30-38 x 3-4 $\mu \mathrm{m}$ dan memiliki 3 sekat. Penyebarannya luas dan ditemukan pada bagian buah kakao

\section{Fusarium solani var. coeruleum (Sacc)}

Konidia yang muda tidak memiliki sekat, setelah dewasa bersekat, jumlah sekat 4-5, berbentuk curved atau melengkung, permukaan konidia halus. Panjang konidia $52 \mu \mathrm{m}$, lebar 3 $\mu \mathrm{m}$, ditemukan pada bagian buah kakao 


\section{Fusarium decemcellulare Brick.}

Konidia berbentuk melengkung, bagian ujung runcing, jumlah sekat 7-10. Memiliki ukuran panjang 55-130 $\mu \mathrm{m}$, ditemukan di buah kakao

\section{KESIMPULAN}

Berdasarkan hasil penelitian dapat disimpulkan bahwa pada tanaman kakao di Kabupaten Pesawaran ditemukan 16 jenis jamur yang termasuk dalam 4 kelas. Satu jenis termasuk ke dalam kelas Oomycetes, Satu jenis termasuk ke dalam kelas Zygomycetes, 13 jenis termasuk ke dalam kelas Deutero-mycetes dan satu jenis termasuk ke dalam kelas Basidiomycetes.

\section{DAFTAR PUSTAKA}

Barnett, H.L. and Hunter, B.B. 1998. Illustrated Genera of Imperfecti Fungi. Burgess Publishing Company. Minneapolis.

Booth, C. 1971. The Genus Fusarium. Commonwealth Mycological Institute.Kew.

Brunt, A. A. F. \& Wharton, A.L. 1962. Fusarium decemcellulare. Biol .50:283 -289

Chupp, C. 1953. A Monograph of The Fungus Genus Cercospora. Cornell University. Ithaca, New York.

Cooke, A.W, Jacobi, K. K. and Ledger, S.N.. 2004. Control of Postharvest Diseases of Mango.

(Online).http://plp3002.ifas.ufl.edu/pdfs/lecture /postharvest.pdf. diakses 12 September 2003. 10.00

Departemen Pertanian. 2012. Kakao. http://www.litbang.deptan.go.id/special/ko moditas/b4kakao. diakses tanggal 18 April, 10.00

Dinas Perkebunan Lampung. 2013. Komoditi Perkebunan Kakao. Dinas Perkebunan Provinsi Lampung. Lampung.

Direktorat Jenderal Perkebunan. 2012. Statistik Perkebunan Indonesia. Direktorat Jenderal Perkebunan Indonesia. Jakarta.

Ellis, M.B. 1971. Dematiaceous Hyphomycetes $X$. Commonwealth Mycological Institute.Kew.
Ellis, M.B. 1976. More Dematiaceous Hyphomycetes. Commonwealth Mycological Institute.Kew.

Hanlin,R. T. 1989. Illustrated Genera of Ascomycetes. The American Phytopathological Society, Minnesota 55121-2097, USA.

Hislop, E. C. 1964. "Black Pod Disaese", Cacao Grower Bulletin.

Leslie, J.F and Kleint, K K.. 1996. Female Fertility and Mating Type Effects on Effective Population Size and Evolution in Filamentous Fungi. Departement of Plant Pathology. Kansas State University (On line)

http://www.genetics.org/content/144/2/557. full.pdf. diakses tanggal 29 Januari 2013. Pukul 22. 44 WIB

Junianto. 1993, Teknik Pengendalian Penyakit Utama pada Kakao Mulia (Theobroma cacao L.) di Kaliwining. Pelita Perkebunan, Jakarta.

Pemerintah Kabupaten Pesawaran. 2010. Pesawaran.http://pesawarankab.go.id. Diakses tanggal 24 Maret 2013. Pukul 11.30 WIB

Samosir, J. 2007. Inventarisasi Jamur Penyebab Penyakit Pada Tanaman Stroberi (Fragaria vesca L.) Di Kecamatan Berastagi (Skripsi). Universitas Sumatera Utara. Medan.

Semangun, H. 2000. Penyakit-penyakit Tanaman Perkebunan di Indonesia. UGM Press. Yogyakarta.

Subowo, Y.B. 2009. Isolasi dan Seleksi Jamur Aphyllophorales Pengurai Lignin Di Hutan Bukit Bangkirai, Kalimatan Timur. Bidang Mikrobiologi Pusat Penelitian Biologi LIPI. Jakarta.

Sunanto, H. 1992. Budidaya Coklat, Pengolahan Hasil, dan Aspek Ekonominya, Kanisius, Jakarta.

Sutton, B.C. 1980. The Coleomycetes Fungi Imperfecti with Pycnidia, Acervuli and Stromata. Common wealth Mycological Institute. Kew.

Zaenudin. 2010. Buku Pintar Budidaya Kakao. Agromedia Pustaka, Jakarta. 


\section{LAMPIRAN}

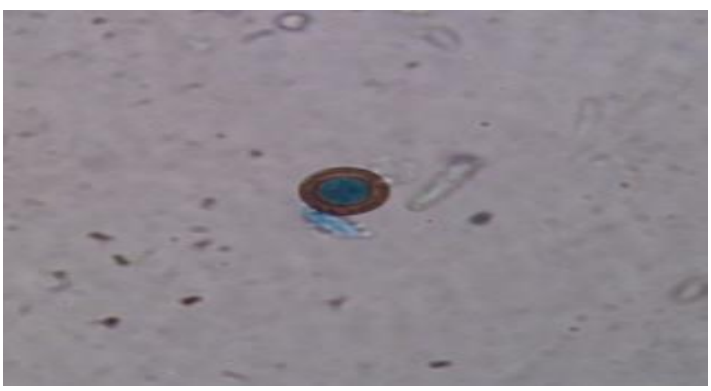

Gambar 1. Konidia Periconia sp

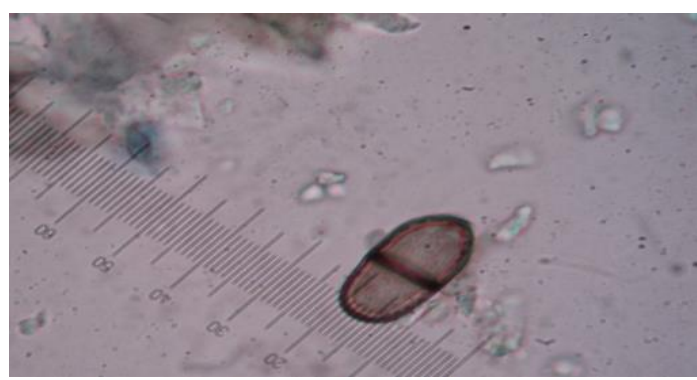

Gambar 2. Konidia Botryodiplodia theobromae

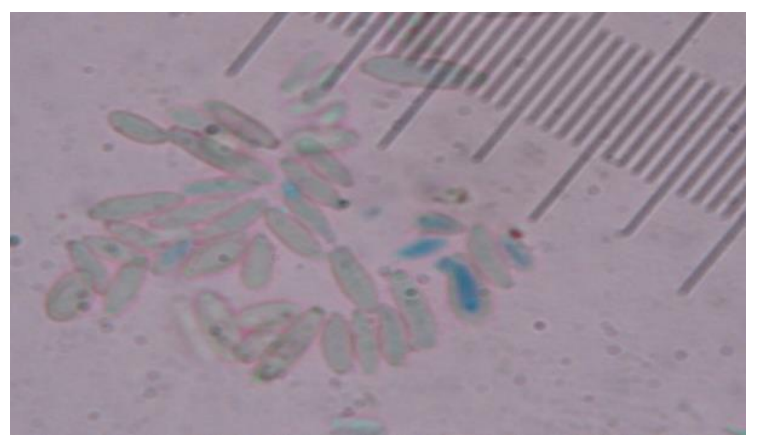

Gambar 3. Konidia Cladosporium tenuissimum

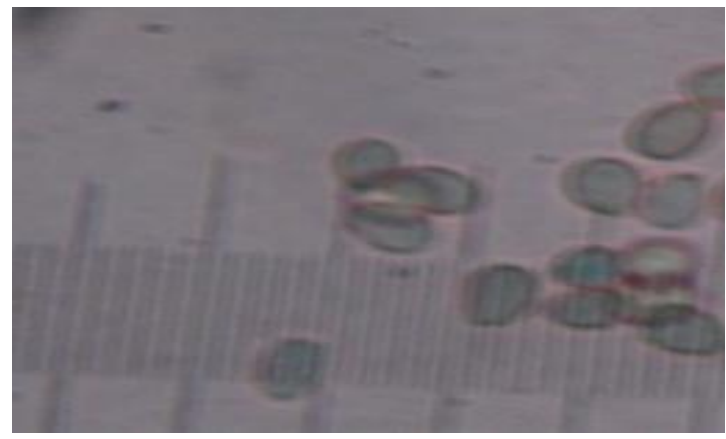

Gambar 4. Konidia Botrytis cinerea

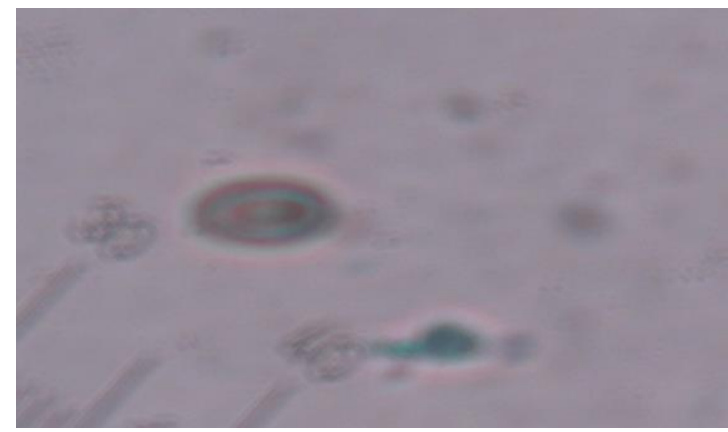

Gambar 5. Konidia Phytophthora palmivora

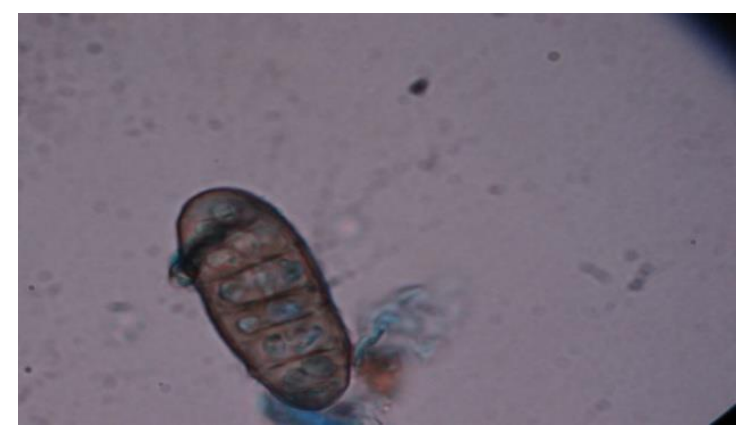

Gambar 6. Konidia Drechslera teres

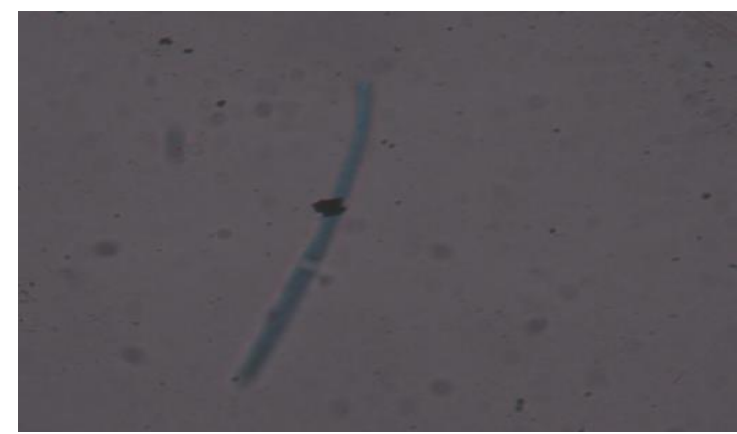

Gambar 7. Konidia Cercospora sp.

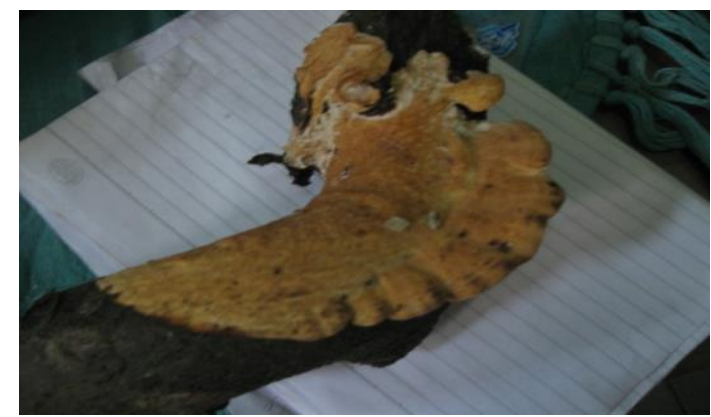

Gambar 8. Ganoderma pseudoferreum 


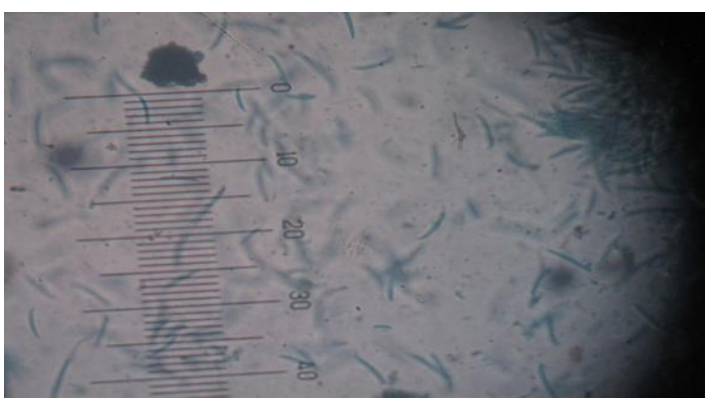

Gambar 9. Konidia Colletotrichum capsici

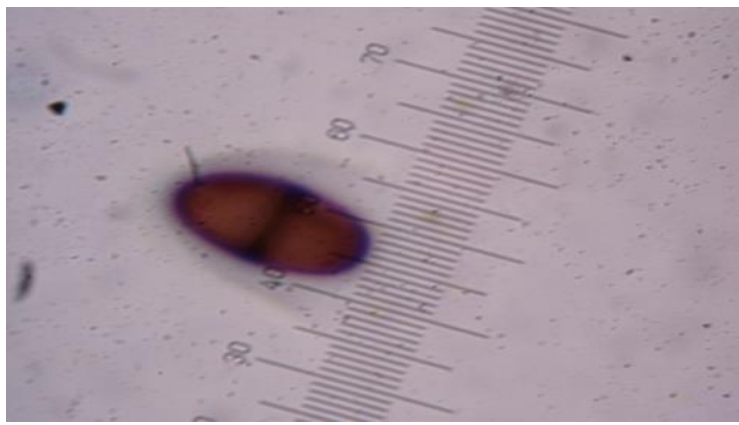

Gambar 10. Konidia Diplodina sp.

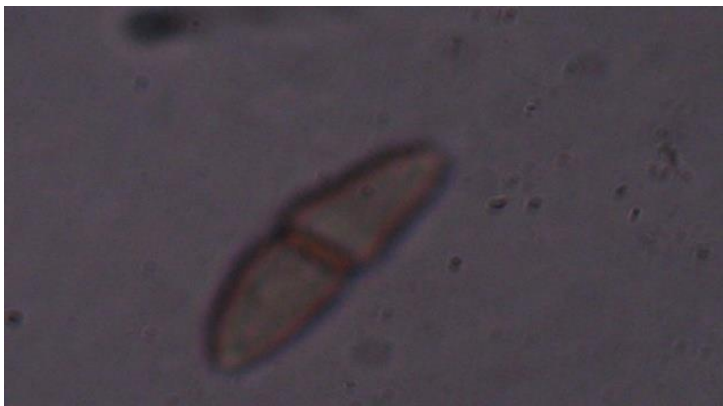

Gambar 11. Konidia Hysteropycnis sp

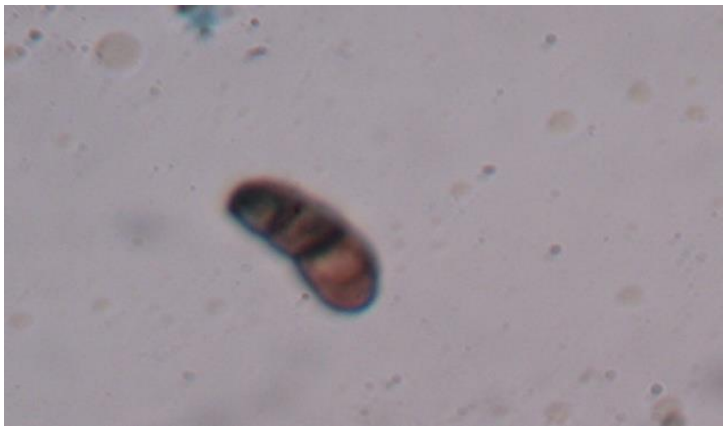

Gambar 12. Konidia Hendersonia sp

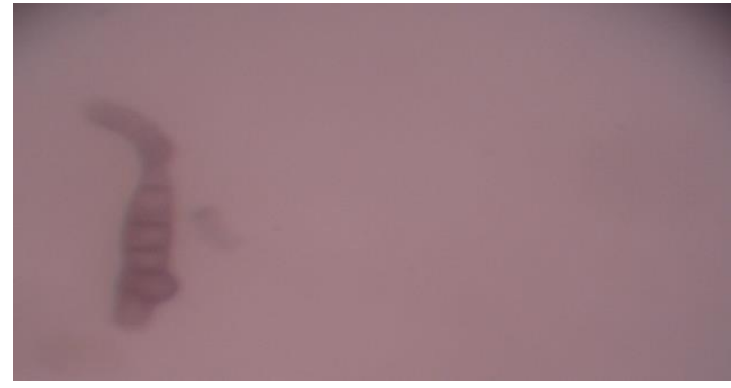

Gambar 13. Konidia Alternaria raphani

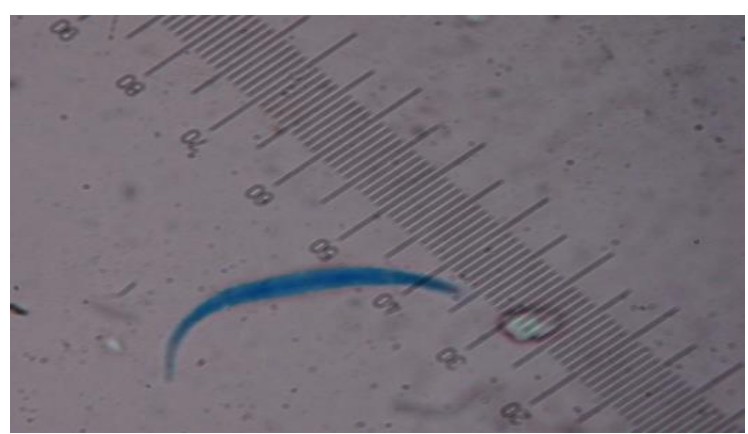

Gambar 14. Kondia Fusarium Acuminatum

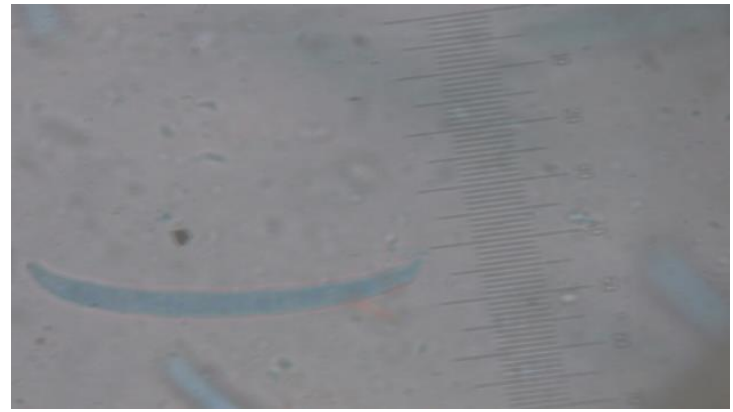

Gambar 15. Konidia Fusarium solani

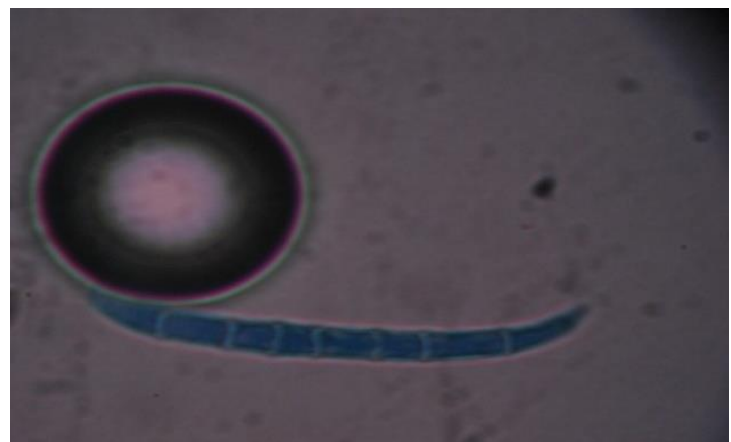

Gambar 16. Konidia Fusarium decemcellulare 